\title{
VARIABILITY OF CHEMICAL WEATHERING INDICES IN MODERN SEDIMENTS OF THE VISTULA AND ODRA RIVERS (POLAND)
}

\author{
NADŁONEK, $\mathrm{W}^{{ }^{*}}{ }^{*}$ - BOJAKOWSKA, I. ${ }^{2}$ \\ ${ }^{I}$ Faculty of Earth Sciences, University of Silesia, Będzińska 60, 41-200 Sosnowiec, Poland \\ ${ }^{2}$ Polish Geological Institute - National Research Institute \\ Rakowiecka 4, 00-975 Warszawa, Poland \\ *Corresponding author \\ e-mail:weronika.nadlonek@interia.pl \\ (Received $10^{\text {th }}$ Jan 2018; accepted $19^{\text {th }}$ Apr 2018)
}

\begin{abstract}
The survey was conducted to determine chemical weathering indices in modern river sediments in Poland. Weathering Index of Parker (WIP), Chemical Index of Alteration (CIA), Vogt's Residual Index (V), Harnois's Chemical Index of Weathering (CIW), and Plagioclase Index of Alteration (PIA) was calculated for 178 sediment samples taken from the Vistula River and its tributaries as well as for 114 samples from the Odra River and its tributaries. The indices values were in the ranges: WIP 0.5-20; CIA 4-80; V 0.1-2.8; CIW 4-82; and PIA 3-81.7. The observed variation of values resulted from a varied sample lithology and varied climatic conditions in the Poland area. Sediments from the upper parts of the Odra and the Vistula drainage basins (southwestern part of the country), where pre-Quaternary rocks are exposed, are more resistant to chemical weathering and characteristic for lower susceptibility to leaching of elements. The highest elements losses due to leaching are characteristic for samples taken from the lower parts of the Odra and the Vistula drainage basins, dominated by Quaternary deposits. Additionally, it was found that larger indices values, reflecting effects of stronger weathering, are observed in the southwestern part of the country (with the warmer and more humid climate) comparing to the northeastern part (with prevailed colder and drier climatic conditions).
\end{abstract}

Keywords: river sediments, indices of chemical weathering, drainage basins, Poland, moderate climate, lithology

\section{Introduction}

The chemical composition of modern river sediments is affected by many factors, primarily the lithology of river basins and climatic conditions. However, there are also other important factors, including topography of the terrain, vegetation type, and land use of the drainage area (Bahlburg and Dobrzinski, 2011).

Sediments that accumulate on the river bottom are derived from material originating from erosion and the weathering of rocks occurring within the drainage area (e.g. quartz grains, feldspars, carbonates, clay minerals and heavy metals) and from in-situ material (debris of dead plants and animals, and minerals precipitated from water, e.g. goethite, fluoroapatite and makinavite). In industrialised, urbanised and agricultural areas, the sediment is also enriched in organic and inorganic contaminants contained in wastewater discharged into the surface water, as well as those transported by surface runoff (Bojakowska et al., 2006; Ciszewski, 1997, 2002, 2005; Cempiel et al., 2014).

Under surface conditions, clay minerals (notably illite and kaolinite) and iron hydroxides, e.g. goethite, form within weathering covers due to chemical weathering of unstable minerals, especially feldspars. The weathering covers are also depleted in $\mathrm{Ca}^{2+}$, $\mathrm{K}^{+}, \mathrm{Na}^{+}$and $\mathrm{Mg}^{2+}$ ions as a consequence of their leaching (Fedo et al., 1995; Bland and 
Rolls, 1998; Bahlburg and Dobrzinski, 2011). As a result of erosion, material from the weathering covers and soils is transferred to river channels and partly deposited there.

To reflect the intensity of chemical weathering processes and to determine the degree of depletion of soils and river sediments in mobile components relative to immobile ones due to the weathering process, the chemical weathering indices are used (Price and Velbel, 2003). They are widely employed in research of both modern and fossil weathering profiles and marine and lacustrine sediments (Harnois, 1988; Nesbitt and Young, 1982; Bäumler and Zech, 2000). The weathering indices are also useful for monitoring the variability of components in longitudinal river profiles, and for evaluating soil fertility and development (Chetelat et al., 2013; Li and Yang, 2010; Bilinski, 2008; Shao et al., 2012; Price and Velbel, 2003 after Delvaux et al., 1989). These indices reflect the effects of climate on the weathering of parent rocks, characterise neotectonic-related transformation, quantify the properties of the regolith, and allow for a better explanation of elemental mobility during weathering processes (Neall, 1977; Fedo et al., 1996; Sharma and Rajamani, 2000). The ideal index should allow for a comparison of studies carried out at different locations, on various materials, and in weathering profiles of different ages. The index should also be easy to apply and based on elements commonly found in surface environments (Harnois, 1998).

The purpose of the study was to determine the factors affecting significantly the weathering of sediments based on variations in the values of weathering indices in the Vistula and Odra river basins. The results of geochemical studies carried out within the framework of the National Environmental Monitoring (PMS) were used.

\section{Weathering indices}

The most frequently used weathering indices are: Weathering Index of Parker (WIP), Chemical Index of Alteration (CIA), Chemical Index of Weathering (CIW), Vogt's Residual Index (V), and Plagioclase Index of Alteration (PIA) (Table 1). They are sensitive even to minor geochemical changes such as hydrothermal alterations along fault lines, and groundwater level fluctuations.

Table 1. Chemical weathering indices

\begin{tabular}{c|c|c}
\hline Index & Formula & Reference \\
\hline $\begin{array}{c}\text { Weathering Index of } \\
\text { Parker (WIP) }\end{array}$ & $W I P=\left(\frac{2 \mathrm{Na}_{2} \mathrm{O}}{0.35}+\frac{\mathrm{MgO}}{0.9}+\frac{2 \mathrm{~K}_{2} \mathrm{O}}{0.25}+\frac{\mathrm{CaO}}{0.7}\right) \times 100$ & Parker (1970) \\
\hline $\begin{array}{c}\text { Vogt's Residual } \\
\text { Index (V) }\end{array}$ & $\mathrm{V}=\frac{\mathrm{Al}_{2} \mathrm{O}_{3}+\mathrm{K}_{2} \mathrm{O}}{\mathrm{MgO}+\mathrm{CaO}+\mathrm{Na}_{2} \mathrm{O}}$ & Vogt (1927) \\
\hline $\begin{array}{c}\text { Chemical Index of } \\
\text { Alteration (CIA) }\end{array}$ & $\mathrm{CIA}=\frac{\mathrm{Al}_{2} \mathrm{O}_{3}}{\mathrm{Al}_{2} \mathrm{O}_{3}+\mathrm{CaO}+\mathrm{Na}_{2} \mathrm{O}+\mathrm{K}_{2} \mathrm{O}} \times 100$ & $\begin{array}{c}\text { Nesbitt and Young } \\
\text { (1982) }\end{array}$ \\
\hline $\begin{array}{c}\text { Chemical Index of } \\
\text { Weathering (CIW) }\end{array}$ & $\mathrm{CIW}=\frac{\mathrm{Al} l_{2} \mathrm{O}_{3}}{\mathrm{Al}_{2} \mathrm{O}_{3}+\mathrm{CaO}_{\mathrm{Na}} \mathrm{O}} \times 100$ & Harnois (1988) \\
\hline $\begin{array}{c}\text { Plagioclase Index of } \\
\text { Alteration (PIA) }\end{array}$ & $\mathrm{PIA}=\frac{\mathrm{Al} \mathrm{O}_{3}-\mathrm{K}_{2} \mathrm{O}}{\mathrm{Al}_{2} \mathrm{O} 3+\mathrm{CaO}_{2} \mathrm{Na}_{2} \mathrm{O}-\mathrm{K}_{2} \mathrm{O}} \times 100$ & Fedo et al. (1995) \\
\hline
\end{tabular}


Weathering Index of Parker (WIP) involves the mobility of sodium, potassium, magnesium and calcium during weathering processes. These are the most mobile major elements and therefore the index is not recommended for the analysis of strongly weathered material (Eswaran et al., 1973; Price and Velbel, 2003). The index of Parker is most useful for reflecting changes in the amount of $\mathrm{Na}^{+}, \mathrm{K}^{+}, \mathrm{Ca}^{2+}$ and $\mathrm{Mg}^{2+}$ cations, if the alteration of feldspars into clay minerals is the major chemical (hydrolytic) weathering process, and there are similar mobilities between the major cations (Parker, 1970). The WIP is the appropriate index for the assessment of weathering of rocks where hydrolysis is the main weathering process (Gupta and Rao, 2001). The WIP value is in the range from 0 to 100 , and its maxima correspond to the least weathered rocks.

The source of inaccuracy in calculating the index is the assumed simplification that the total amount of calcium in the rock is contained in silicate minerals. This simplification is particularly disadvantageous if the rock contains large amounts of detritus or carbonate cement. Doubts also arise as to not involving relatively immobile phases, such as $\mathrm{Al}_{2} \mathrm{O}_{3}$, in the formula, which makes it impossible to observe changes in the composition of essential minerals (Bahlburg and Dobrzinski, 2011). The disadvantages of the WIP are eliminable using the Chemical Index of Alteration (CIA) that involves all geochemical data of the rock (Nesbitt and Young, 1982).

Vogt's Residual Index (V) is defined by the ratio of the amount of oxides of immobile cations (mainly Al) to mobile cations (magnesium, calcium and sodium) with the assumption that the potassium content remains constant during the weathering process (Haskins, 2006). This index is an attempt to determine the maturity of residual sediments, and its greater value indicates higher intensity of weathering processes (Price and Velbel, 2003; Haskins, 2006). Vogt's index was used to compare the chemistry of glacial tills and marine clay deposits, showing that glacial tills are much more heavily weathered than marine clays. This suggests that the weathering process ended before deposition of marine sediments (Roaldset, 1972).

Chemical Index of Alteration (CIA) is the most commonly used proxy in research of fluvial deposits. Its value clearly reflects an increase in weathering intensity of silicates from the river's lower to upper reach. Evaluation of CIA values combined with a comprehensive facies analysis allows for a precise approximation of chemical and physical weathering conditions in the past (Shao et al., 2012).

The CIA illustrates the ratio of $\mathrm{Al}_{2} \mathrm{O}_{3}$, mostly immobile during weathering, to the mobile cations $\mathrm{Na}^{+}, \mathrm{K}^{+}$and $\mathrm{Ca}^{2+}$ (Bahlburg and Dobrzinski, 2011). High CIA values indicate washing out of the mobile $\mathrm{Ca}^{2+}, \mathrm{Na}^{+}$and $\mathrm{K}^{+}$cations during weathering in relation to immobile components $\left(\mathrm{Al}^{3+}, \mathrm{Ti}^{4+}\right)$ (Nesbitt and Young, 1982). Its low values suggest lack of chemical alterations and cool and/or arid climate conditions (Fedo et al., 1995). The greatest CIA value (up to 100) is typical of kaolinite weathering. For illite the figures vary between 75 and 90 , for muscovite it is 75 , and for feldspars 50 . Fresh basalts show CIA values in the range of 30-45, and fresh granites and granodiorites 4550 (Nesbitt and Young, 1982; Fedo et al., 1995).

Harnois's Chemical Index of Weathering (CIW) is calculated similarly to the CIA, eliminating only the $\mathrm{K}_{2} \mathrm{O}$ contribution. In the calculations, aluminium, which is associated with potassium feldspars, is not separated, thus the CIW can reach very high values in the case of rocks rich in these minerals, no matter whether the rocks are chemically weathered or not (Fedo et al., 1995).

Plagioclase Index of Alteration (PIA) has been proposed as a substitute for the CIW. It is particularly applicable for the separate monitoring of weathering of plagioclases. 
The PIA attains values of 50 in non-weathered rocks and close to 100 in clay minerals such as kaolinite, illite and gibbsite, in accordance with the values derived from the CIA formula.

\section{Study area and research methods}

\section{Characteristics of the study area}

The Vistula River basin covers an area of $183,176 \mathrm{~km}^{2}$, which is ca. $59 \%$ of the total land area of Poland. According to the physic-geographical regionalization, the Vistula River basin is located within the following subprovinces: Central Western Carpathians, Outer Western Carpathians, Eastern Beskids, Eastern Subcarpathia, Northern Subcarpathia, Silesian-Cracow Upland, Małopolska Upland, Lublin-Lviv Upland, Polesie, Central Polish Lowlands, Podlasie-Belarus Uplands, South Baltic Lakelands, East Baltic Lakelands, Southern Baltic Coast, and Eastern Baltic Coast (Kondracki, 2009).

In the Upper Vistula River basin, which is a very diverse area in terms of geology, there are pre-Quaternary deposits. The most elevated part of the basin, the Tatra Mountains, is composed partly of crystalline rocks (gneisses, schists and granites) and sedimentary rocks (conglomerates, quartzites, clays, limestones, and marls). The Pieniny Klippen Belt is composed of Jurassic-Cretaceous and Paleogene carbonates. In Podhale, there are Paleogene sandstones and shales, while the Outer Carpathians are built of sandstones and shales, the so called flysch. Outcrops of pre-Quaternary rocks are also found in the Lublin Upland (Cretaceous limestones and marls), Małopolska Upland (limestone and marls in the Nida Trough), Holy Cross Mountains (limestones, dolomites, sandstones and quartzites) and Silesian-Cracow Upland (conglomerates, limestones, dolomites, clays and sandstones) (Marks et al., 2006).

Most of the Lower Vistula River basin area is covered by Quaternary deposits. These are Pleistocene glacial tills, ice-dammed lake clays, glaciofluvial and fluvial sands, fluvial gravels and sands, and peats and muds. Some areas of the Małopolska Upland and Lublin Upland are covered by loess and loess-like deposits. The river valleys are filled with Holocene alluvial and fluvial muds, sands and gravels (Marks et al., 2006).

The Odra River basin covers an area of $118,861 \mathrm{~km}^{2}$ (of which $106,056 \mathrm{~km}^{2}$ in Poland), including the Warta River basin of $54,529 \mathrm{~km}^{2}$. In the physic-geographical regionalization of Poland, the Odra River basin is located within the area of the following subprovinces: the Sudetes and Sudetes Foothills, Central Polish Lowlands, Silesian-Lusatian Lowlands, South Baltic Lakelands, and Southern Baltic Coast (Kondracki, 2009). Almost the entire area of the Odra River basin is covered by Quaternary glacial and fluvial deposits (tills, sands, muds, peats) (Kondracki, 2009). In some places, for example in the Opawa River basin, Quaternary loess is found. In the Sudetes area, situated in the southwestern part of the drainage basin (upper reaches of the Odra River's left tributaries: the Kwisa, Bóbr and Orlica), pre-Quaternary magmatic, metamorphic and sedimentary rocks are exposed on the surface. The oldest rocks include gneisses, granitogneisses and migmatites of the Sudetes Mountains. In the Kaczawskie Mountains, Kłodzko region, and north of Strzegom, in the Sudetes Foreland, there are rocks metamorphosed in the much shallower, so called greenschist zone. These are various types of phyllites (which are metamorphosed mudstones and clay shales), metasandstones, metavolcanites, and crystalline limestones. 
Sedimentary rocks of the Sudetes are represented by conglomerates, sandstones, greywackes, mudstones and clay shales. In the Paleozoic, two basic groups of igneous rocks were formed: (1) gabbro, peridotites and serpentinites (Nowa Ruda-Słupca, Ząbkowice Śląskie (Szklary) region in the Sudetes Foreland, Ślęża and its vicinity and (2) granites (Karkonosze Ridge, the massifs between Złoty Stok and Kłodzko, Kudowa region). Younger sedimentary formations are represented in the Sudetes and their foreland by the Upper Permian limestones, marls and gypsum, Triassic red sandstones and mudstones, as well as limestones and marls, and Upper Cretaceous sandstones and marls (Table Mountains, and the vicinity of Lwówek Śląski, Wleń, Bystrzyca Kłodzka and Międzylesie). This area was covered by Quaternary ice sheets, resulting in the accumulation of glacial, fluvial, eolian and slope deposits: various types of clays, sands, gravels, loesses and alluvial muds (Cwojdziński and Kozdrój, 2007).

Fluvial sediments in the area of Poland are dominated by quartz; carbonates and feldspars are present in smaller quantities. These components are represented by grain fractions $>0.06 \mathrm{~mm}$, which usually account for more than $90 \%$ of the sediment. This material originates mainly from the erosion of rocks occurring in the drainage basin. Fine-grained fractions $(<0.06 \mathrm{~mm})$ contain mostly minerals of the mica/illite group, and quartz, kaolinite and chlorite. Carbonates, feldspars, pyroxenes and amphiboles are less frequent. Significant amounts of organic matter and hydrated iron and manganese oxides are also present (Bojakowska and Sokołowska, 1998).

The area of Poland lies within the transitional climate zone. Change of isotherms system depending on season from latitudinal to longitudinal is a characteristic feature of Poland's climate. Summer temperature drop from south to north is connected with the increase of latitude. Winter temperature drop from west to east is in contrast conditioned by atmospheric circulation. In spatial distribution of temperatures Baltic coast is the warmest in the coldest months, whilst mountain peaks are the coldest. In July predominant part of Poland has the average temperature about $17.0-18.0{ }^{\circ} \mathrm{C}$ (Richling and Ostaszewska, 2005). The lowest average annual air temperatures are characteristic for the highest areas. Generally, besides mountain areas average annual air temperatures lower than $7{ }^{\circ} \mathrm{C}$ are distinctive for eastern part of Masurian Lake District and Region of Podlasie (Woś, 2010).

In Poland, similarly like in western and northern Europe, south-westerly, westerly and north-westerly winds are dominant. Wind field is deformed by Baltic Sea, lakes and land relief (mountains) (Richling and Ostaszewska, 2005).

"Zoning" is the most significant feature of spatial distribution of total annual precipitation on the area of Poland. Lowland zone receives below $600 \mathrm{~mm}$ of precipitation per year, so less than the average annual rainfall. Especially small rainfalls occur in the central Poland (about $500 \mathrm{~mm}$ ). In the north of the country rainfall is larger, but precipitation level does not achieve there $700 \mathrm{~mm}$. Precipitation increases together with elevation above sea level towards south from lowlands zone in central Poland. And so, Małopolska and Lubelska Upland receive on average over $550 \mathrm{~mm}$ of precipitation, and Holy Cross Mountains zone over $650 \mathrm{~mm}$. Precipitation amounts quickly increase southwards and in the highest parts of the Tatra Mountains elevate even 1600$1700 \mathrm{~mm}$. In the Sudetes precipitation levels are sometimes higher than at the same heights in the Carpathians (1200-1300 mm). Sudeten Foreland receives in turn less rainfalls than the Carpathian Foothills, what is associated with different land relief (Richling and Ostaszewska, 2005). 


\section{Research methods}

The research is based on results of analyses of 178 sediment samples collected from the Vistula River and its tributaries (Bug, Dunajec, San, Pilica, Bzura and Narew rivers) and 114 sediment samples from the Odra and Warta rivers and their tributaries (Nysa Łużycka, Bóbr, Kwisa, Kaczawa, Bystrzyca, Barycz, Nysa Kłodzka and Mała Panew rivers). The sediments were analysed within the framework of the National Environmental Monitoring (PMŚ) in 2015. Sampling sites are shown in the sketch map (Fig. 1). Sediment samples were collected at sites located along the rivers, downstream of the mouths of tributary rivers and other watercourses longer than $50 \mathrm{~km}$, and downstream of major cities or towns where industrial plants are located.

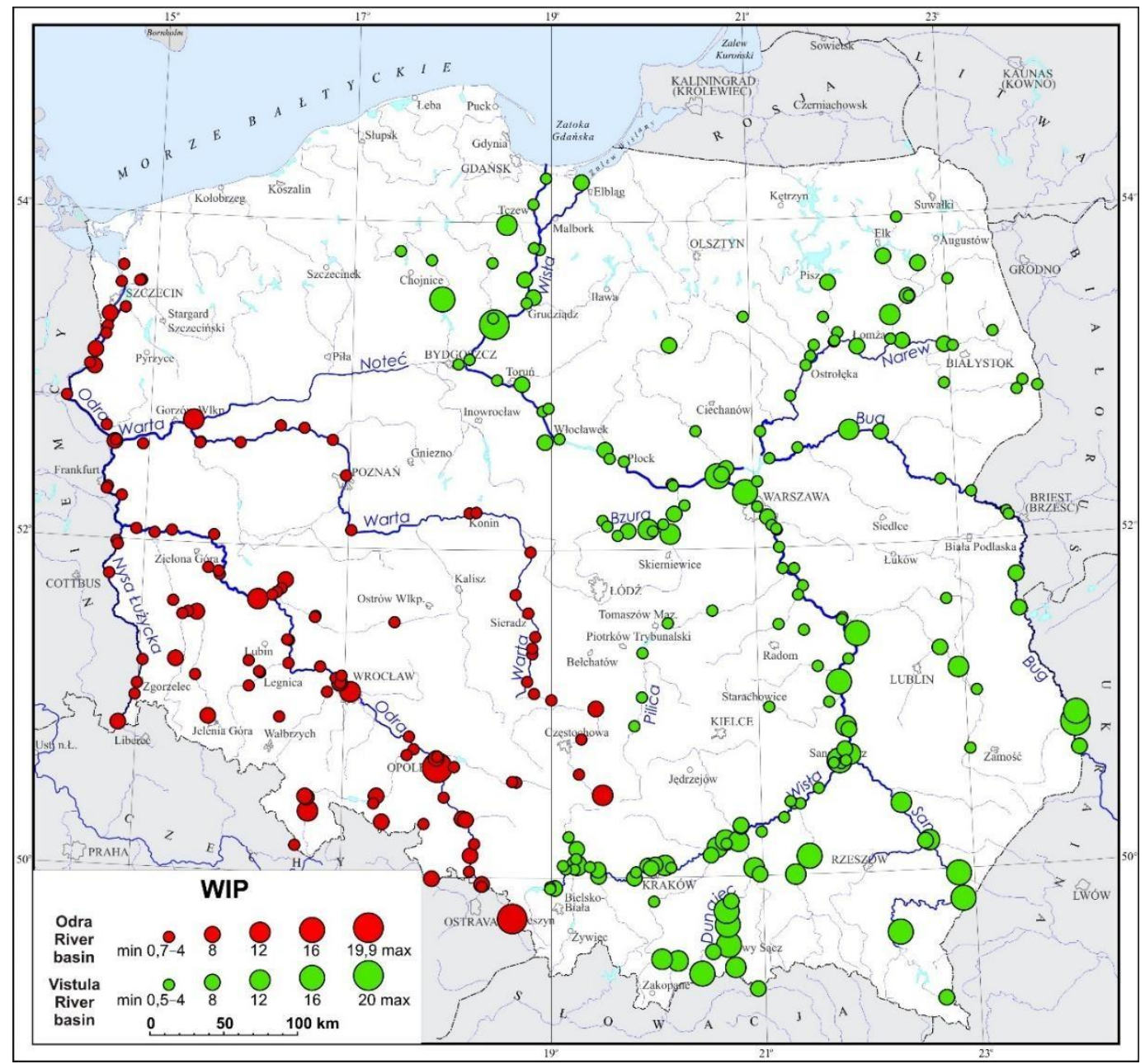

Figure 1. Sampling sites and Weathering Index of Parker values

Sediment samples were taken with an aluminium scoop from river banks, where the accumulating sediment is characterised by the highest content of the mud and clay fraction (Fig. 2). Each sample was an averaged sample of four or five samplings from a $5-\mathrm{cm}$ thick surface sediment layer over a stretch of about $50 \mathrm{~m}$. The sediment samples were dried at room temperature and then sieved through nylon sieves with a mesh size of $0.2 \mathrm{~mm}$. The $\mathrm{Al}, \mathrm{Ca}, \mathrm{Mg}, \mathrm{K}$ and $\mathrm{Na}$ concentrations were determined using atomic 
plasma emission spectrometry (ICP-OES) after digestion of the samples in aqua regia (Fig. 3). The detection limits were $0.01 \%$ for $\mathrm{Al}, \mathrm{Ca}, \mathrm{Mg}$ and $\mathrm{K}$, and $0.001 \%$ for $\mathrm{Na}$.

Results of the $\mathrm{Al}, \mathrm{Ca}, \mathrm{Mg}, \mathrm{K}$ and $\mathrm{Na}$ determinations were used to calculate WIP, $\mathrm{V}$, CIA, CIW and PIA values according to the formulas shown in Table 1 (molecular proportions of oxides).

Statistical parameters (the minimum, maximum, median, mean and geometric mean) for the contents of elements and the calculated weathering indices were determined using the Statistica program. Maps of the variability of weathering indices in sediments were compiled using ArcGIS software.

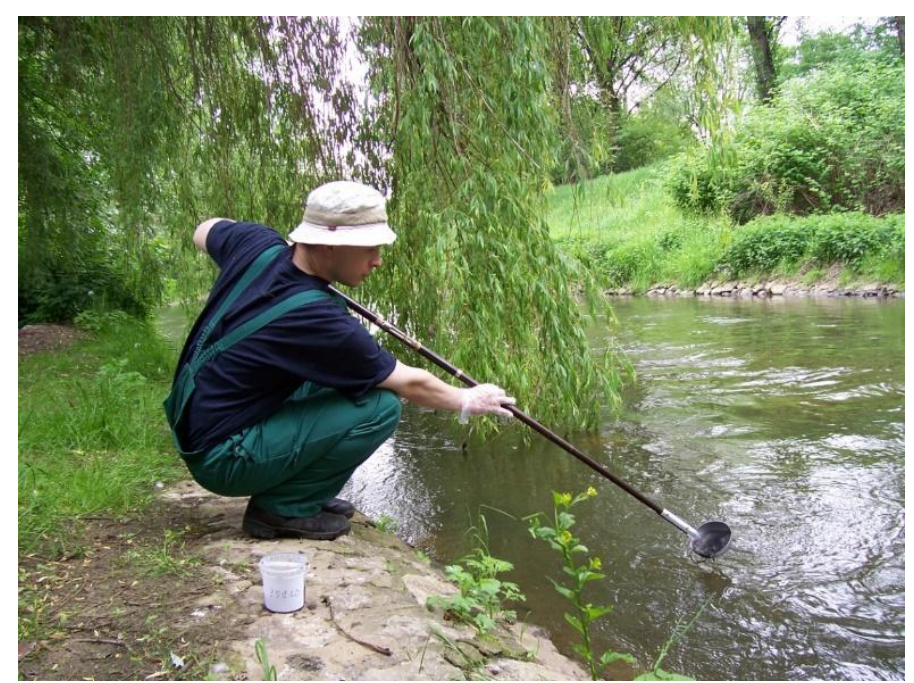

Figure 2. River sediment sampling in the Vistula River basin. (Photo: A. Dusza-Dobek)

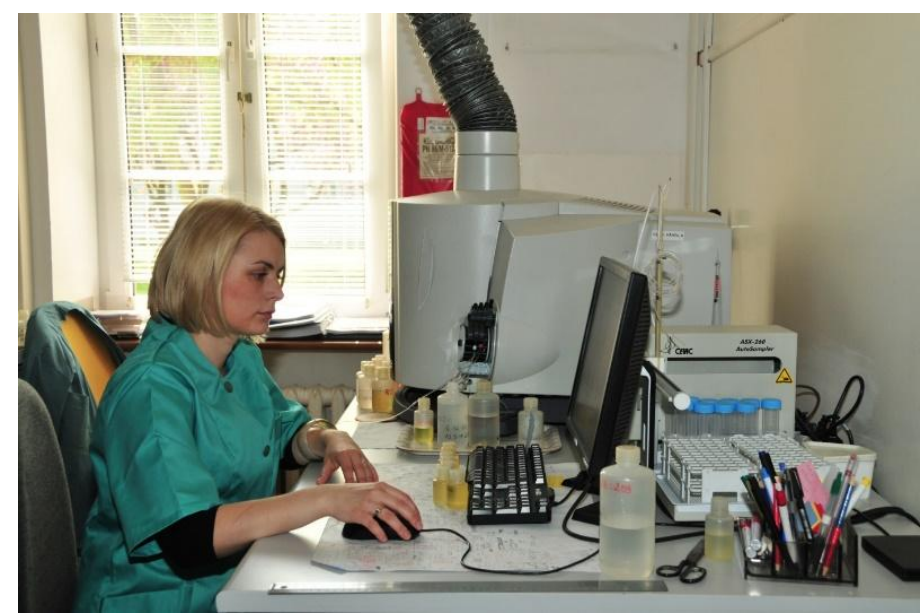

Figure 3. iCAP 6500 duo Thermo Scientific ICP-OES instrument used for determination of analysed chemical elements. (Photo: I. Jaroń)

\section{Research results}

The $\mathrm{Al}$ content in sediments of the Vistula River basin ranges from 0.08 to $1.95 \%$, and its mean, geometric mean and median values are $0.39 \%, 0.31 \%$ and $0.28 \%$, respectively (Table 2). The calcium contents vary in the range of $0.04-4.22 \%$, and the 
mean, geometric mean and median values are $0.93 \%, 0.61 \%$ and $0.64 \%$, respectively. The magnesium content varies from 0.01 to $0.92 \%$, and its mean, geometric mean and median values are $0.19 \%, 0.12 \%$ and $0.12 \%$, respectively. The sodium content in sediments of the Vistula River basin ranges from 0.003 to $0.103 \%$; the mean value is $0.014 \%$, the geometric mean $0.012 \%$, and the median $0.011 \%$. The potassium contents range between 0.02 and $0.40 \%$, and its mean, geometric mean and median values are $0.07 \%, 0.06 \%$ and $0.06 \%$, respectively. Standard deviation values for all elements of the Vistula River basin were in a range between 0.01 and 0.84 , whereas coefficient of variation $(\mathrm{CV})$ values were between 71 and 100 (Table 2). Because of the clear variability in the contents of individual elements in the Vistula River basin, the drainage basins of the Dunajec, San, Pilica, Bzura, Bug and Narew rivers have also been discriminated, for which the content ranges of the elements and the mean, geometric mean and median values are determined (Table 2).

Table 2. Statistical parameters of elements content in river sediments

\begin{tabular}{|c|c|c|c|c|c|c|c|}
\hline Element & Mean & $\begin{array}{c}\text { Geometric } \\
\text { mean }\end{array}$ & Median & Minimum & Maximum & $\begin{array}{l}\text { Standard } \\
\text { deviation }\end{array}$ & $\begin{array}{c}\text { Coefficient of } \\
\text { variation }\end{array}$ \\
\hline \multicolumn{8}{|c|}{$\%$} \\
\hline \multicolumn{8}{|c|}{ Vistula River basin (n=178) } \\
\hline Al & 0.39 & 0.31 & 0.28 & 0.08 & 1.95 & 0.31 & 79 \\
\hline $\mathrm{Ca}$ & 0.93 & 0.61 & 0.64 & 0.04 & 4.22 & 0.84 & 90 \\
\hline Mg & 0.19 & 0.12 & 0.12 & 0.01 & 0.92 & 0.19 & 100 \\
\hline $\mathbf{N a}$ & 0.014 & 0.012 & 0.011 & 0.003 & 0.103 & 0.01 & 71 \\
\hline $\mathbf{K}$ & 0.07 & 0.06 & 0.06 & 0.02 & 0.40 & 0.05 & 71 \\
\hline \multicolumn{8}{|c|}{ Bug $(n=12)$} \\
\hline Al & 0.28 & 0.25 & 0.32 & 0.09 & 0.48 & 0.12 & 43 \\
\hline $\mathbf{C a}$ & 1.52 & 1.05 & 1.26 & 0.21 & 4.22 & 1.28 & 84 \\
\hline Mg & 0.10 & 0.08 & 0.09 & 0.03 & 0.24 & 0.07 & 70 \\
\hline $\mathbf{N a}$ & 0.009 & 0.008 & 0.009 & 0.004 & 0.015 & 0.003 & 33 \\
\hline $\mathbf{K}$ & 0.06 & 0.05 & 0.05 & 0.02 & 0.11 & 0.03 & 50 \\
\hline \multicolumn{8}{|c|}{ Dunajec $(n=10)$} \\
\hline Al & 0.83 & 0.81 & 0.77 & 0.60 & 1.13 & 0.19 & 23 \\
\hline $\mathbf{C a}$ & 1.55 & 1.41 & 1.42 & 0.61 & 2.52 & 0.67 & 43 \\
\hline Mg & 0.55 & 0.52 & 0.53 & 0.25 & 0.87 & 0.19 & 35 \\
\hline $\mathbf{N a}$ & 0.016 & 0.016 & 0.017 & 0.009 & 0.021 & 0.003 & 19 \\
\hline $\mathbf{K}$ & 0.13 & 0.12 & 0.13 & 0.09 & 0.19 & 0.03 & 23 \\
\hline \multicolumn{8}{|c|}{ San $(n=7)$} \\
\hline Al & 0.59 & 0.58 & 0.56 & 0.42 & 0.78 & 0.12 & 20 \\
\hline $\mathbf{C a}$ & 2.10 & 1.99 & 2.24 & 1.02 & 2.84 & 0.68 & 32 \\
\hline Mg & 0.51 & 0.50 & 0.49 & 0.34 & 0.77 & 0.14 & 27 \\
\hline $\mathbf{N a}$ & 0.016 & 0.015 & 0.016 & 0.008 & 0.021 & 0.005 & 31 \\
\hline $\mathbf{K}$ & 0.12 & 0.12 & 0.13 & 0.07 & 0.15 & 0.03 & 25 \\
\hline \multicolumn{8}{|c|}{ Bzura $(\mathrm{n}=11)$} \\
\hline Al & 0.32 & 0.27 & 0.24 & 0.11 & 0.70 & 0.19 & 59 \\
\hline $\mathbf{C a}$ & 0.86 & 0.67 & 0.79 & 0.19 & 2.08 & 0.60 & 70 \\
\hline Mg & 0.13 & 0.10 & 0.11 & 0.04 & 0.31 & 0.09 & 69 \\
\hline
\end{tabular}




\begin{tabular}{|c|c|c|c|c|c|c|c|}
\hline $\mathbf{N a}$ & 0.017 & 0.012 & 0.011 & 0.004 & 0.073 & 0.02 & 118 \\
\hline $\mathbf{K}$ & 0.06 & 0.05 & 0.05 & 0.02 & 0.11 & 0.03 & 50 \\
\hline \multicolumn{8}{|c|}{ Narew $(n=30)$} \\
\hline Al & 0.19 & 0.19 & 0.19 & 0.11 & 0.42 & 0.06 & 32 \\
\hline $\mathbf{C a}$ & 0.73 & 0.61 & 0.66 & 0.15 & 2.18 & 0.44 & 60 \\
\hline Mg & 0.12 & 0.10 & 0.11 & 0.03 & 0.47 & 0.09 & 75 \\
\hline $\mathbf{N a}$ & 0.011 & 0.011 & 0.011 & 0.007 & 0.019 & 0.002 & 18 \\
\hline $\mathbf{K}$ & 0.05 & 0.05 & 0.05 & 0.03 & 0.07 & 0.01 & 20 \\
\hline \multicolumn{8}{|c|}{ Pilica $(n=13)$} \\
\hline Al & 0.25 & 0.21 & 0.16 & 0.10 & 0.60 & 0.16 & 64 \\
\hline $\mathbf{C a}$ & 0.37 & 0.22 & 0.27 & 0.04 & 1.52 & 0.42 & 114 \\
\hline Mg & 0.06 & 0.04 & 0.03 & 0.02 & 0.25 & 0.07 & 117 \\
\hline $\mathbf{N a}$ & 0.007 & 0.007 & 0.007 & 0.003 & 0.012 & 0.003 & 43 \\
\hline $\mathbf{K}$ & 0.04 & 0.03 & 0.03 & 0.02 & 0.09 & 0.03 & 75 \\
\hline \multicolumn{8}{|c|}{ Odra River basin $(n=114)$} \\
\hline Al & 0.44 & 0.34 & 0.29 & 0.12 & 1.52 & 0.34 & 77 \\
\hline $\mathbf{C a}$ & 0.43 & 0.26 & 0.25 & 0.04 & 4.54 & 0.61 & 142 \\
\hline Mg & 0.13 & 0.08 & 0.06 & 0.01 & 0.69 & 0.14 & 108 \\
\hline $\mathbf{N a}$ & 0.024 & 0.019 & 0.018 & 0.006 & 0.172 & 0.02 & 83 \\
\hline $\mathbf{K}$ & 0.08 & 0.07 & 0.06 & 0.03 & 0.28 & 0.05 & 63 \\
\hline \multicolumn{8}{|c|}{ Warta $(n=26)$} \\
\hline Al & 0.22 & 0.21 & 0.21 & 0.12 & 0.48 & 0.08 & 36 \\
\hline $\mathrm{Ca}$ & 0.41 & 0.23 & 0.22 & 0.04 & 2.41 & 0.62 & 151 \\
\hline Mg & 0.07 & 0.05 & 0.04 & 0.01 & 0.58 & 0.11 & 157 \\
\hline $\mathbf{N a}$ & 0.016 & 0.015 & 0.015 & 0.009 & 0.029 & 0.005 & 31 \\
\hline $\mathbf{K}$ & 0.06 & 0.05 & 0.05 & 0.03 & 0.09 & 0.02 & 33 \\
\hline
\end{tabular}

The $\mathrm{Al}$ content in sediments of the Odra River basin is in the range of $0.12-1.52 \%$, and its mean, geometric mean and median values are similar to those determined in the Vistula River basin (Table 2). The calcium content varies between 0.04 and $4.54 \%$, which is close to the values recorded for sediments from the Vistula River basin, but the mean and median values were below $0.5 \%$. The magnesium content varies in the range of $0.01-0.69 \%$ (the median $0.06 \%$ ), the sodium content is $0.006-0.172 \%$ (the median $0.018 \%$ ), and the potassium content is $0.03-0.28 \%$ (the median $0.06 \%$ ). The mean, geometric mean and median values for magnesium are much higher in the Vistula basin sediments, for sodium in the Odra basin, whereas for potassium the values are very similar (Table 2). Standard deviation values for the elements in the Odra basin varied between 0.02 and 0.61 and coefficient of variation values between 63 and 142. Like with the case of the Vistula and Odra river basins, separate statistical parameters have also been determined for the Warta River basin (Table 2).

The WIP values in sediments of the Vistula River basin varied between 0.5 and 20 , and the mean, geometric mean and median values were 5.1, 3.7 and 3.8, respectively, whereas standard deviation and coefficient of variation values were 4.05 and 79 respectively (Table 3, Fig. 1). The highest value of this index was recorded in sediments of the Fryba River in Chełmno, where the bedrock is represented by limestone, opoka 
(polish name of siliceous-carbonate rock), mudstone and claystone. Values ranging from 17.1 to 13.5 are reported from sediments of the Bug River near the border with Ukraine (limestones and dolomites), and of the Vistula River in Potrawin (limestones, opokas and marls) and Sandomierz (sands, gravels, alluvial muds, Pleistocene peats and muds, with the bedrock composed of loess, limestone, marl and opoka). The lowest WIP value was measured in sediments of the Kamienna River in Starachowice (the bedrock is composed of conglomerates, sandstones and mudstones). Low WIP values are typical of sediments of the Radomka River in Ryczywół, and of the Pilica River in Mniszew (alluvial sands, gravels and muds).

The $\mathrm{V}$ index values in the Vistula drainage basin were in the range between 0.1 (Brda River in Tuchola) and 2.8 (Pszczynka River in Jedlina), with the mean of 0.4, geometric mean 0.3 , median 0.3 , standard deviation 0.32 and coefficient of variation 80 . In the Vistula basin, the highest levels of the chemical weathering index V were found in the tributaries of the Upper Vistula River (Pszczynka, Soła and Iłownica rivers) and in the middle course of the Pilica River (in Spała) (Table 3, Fig. 4). In turn, the lowest values were reported from sediments of the Brda River, middle course of the Wieprz River, Bug River, and the Narew River and its tributaries.

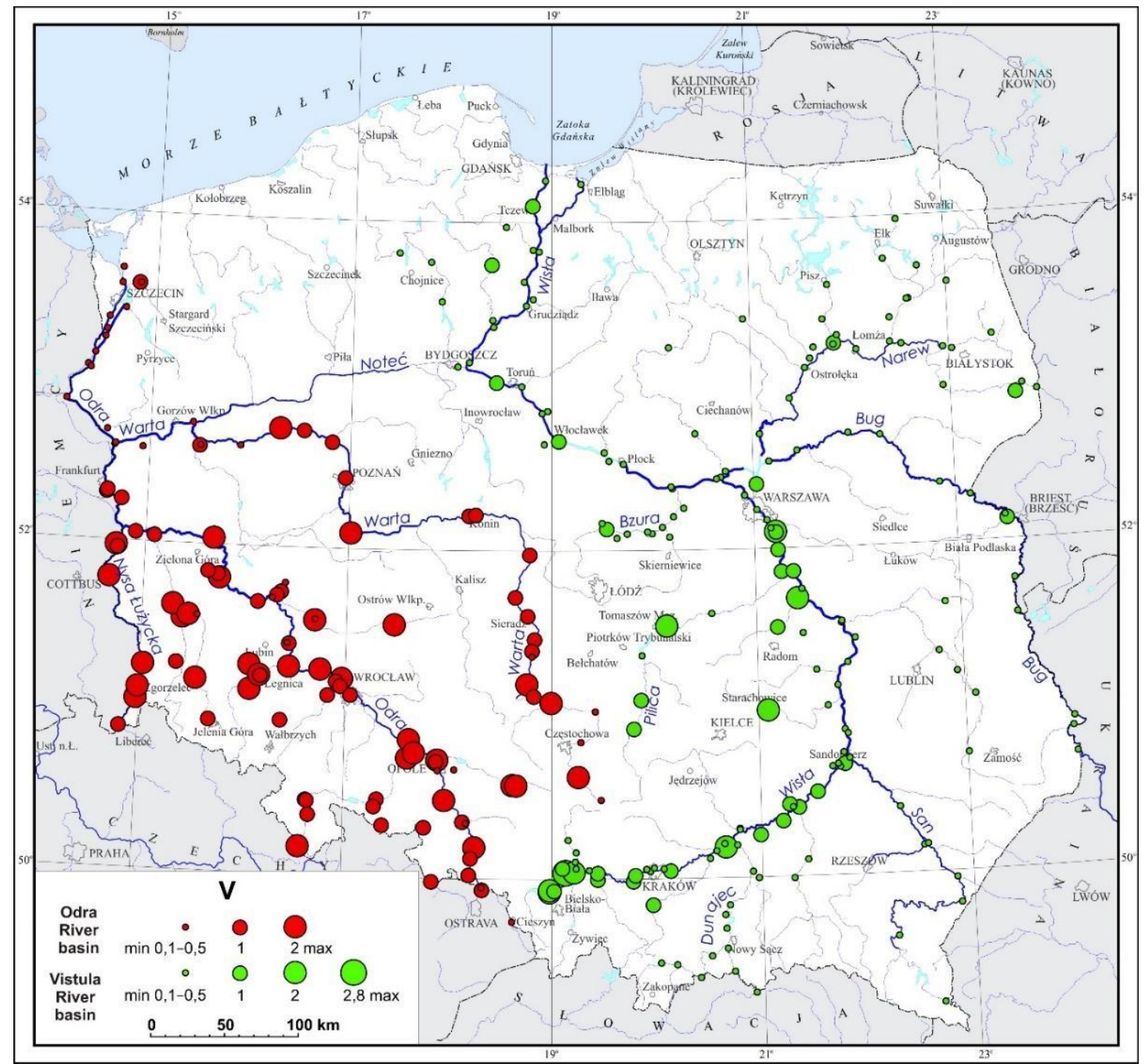

Figure 4. Vogt's Residual Index values 
Table 3. Statistical parameters of chemical weathering indices

\begin{tabular}{|c|c|c|c|c|c|c|c|}
\hline $\begin{array}{c}\text { Chemical } \\
\text { weathering } \\
\text { index }\end{array}$ & Mean & $\begin{array}{c}\text { Geometric } \\
\text { mean }\end{array}$ & Median & Minimum & Maximum & $\begin{array}{l}\text { Standard } \\
\text { deviation }\end{array}$ & $\begin{array}{c}\text { Coefficient of } \\
\text { variation }\end{array}$ \\
\hline \multicolumn{8}{|c|}{$\%$} \\
\hline \multicolumn{8}{|c|}{ Vistula River basin $(\mathrm{n}=178)$} \\
\hline WIP & 5.1 & 3.7 & 3.8 & 0.5 & 20 & 4.05 & 79 \\
\hline $\mathbf{V}$ & 0.4 & 0.3 & 0.3 & 0.1 & 2.8 & 0.32 & 80 \\
\hline CIA & 27.6 & 24.3 & 24.2 & 4 & 80 & 14.07 & 51 \\
\hline CIW & 28.9 & 25.3 & 25 & 4 & 82 & 15.20 & 53 \\
\hline PIA & 26.2 & 22.5 & 22.2 & 3 & 81.7 & 14.79 & 56 \\
\hline \multicolumn{8}{|c|}{ Bug $(n=12)$} \\
\hline WIP & 6.6 & 4.8 & 5.5 & 1.3 & 17.1 & 148.58 & 2251 \\
\hline $\mathbf{V}$ & 0.2 & 0.2 & 0.2 & 0.1 & 0.3 & 0.11 & 55 \\
\hline CIA & 15.4 & 14.2 & 14 & 6.6 & 24.3 & 5.45 & 35 \\
\hline CIW & 15.8 & 14.6 & 14.2 & 6.7 & 25.4 & 6.03 & 38 \\
\hline PIA & 13.8 & 12.8 & 12.7 & 5.9 & 22 & 4.27 & 31 \\
\hline \multicolumn{8}{|c|}{ Dunajec $(n=10)$} \\
\hline WIP & 10 & 9.4 & 9 & 4.5 & 14.7 & 94.47 & 945 \\
\hline $\mathbf{V}$ & 0.3 & 0.3 & 0.2 & 0.2 & 0.6 & 0.16 & 53 \\
\hline CIA & 28.4 & 27.6 & 25 & 21 & 44 & 6.85 & 24 \\
\hline CIW & 29.3 & 28.5 & 25.7 & 21.4 & 45.8 & 7.75 & 26 \\
\hline PIA & 27.1 & 26.3 & 23.6 & 19.8 & 43.5 & 7.17 & 26 \\
\hline \multicolumn{8}{|c|}{$\operatorname{San}(n=7)$} \\
\hline WIP & 11.2 & 11 & 11.7 & 7.7 & 14.4 & 67.70 & 604 \\
\hline $\mathbf{V}$ & 0.2 & 0.2 & 0.2 & 0.1 & 0.4 & 0.14 & 70 \\
\hline CIA & 18.2 & 16.9 & 15.2 & 10.5 & 34.2 & 7.50 & 41 \\
\hline CIW & 18.7 & 17.3 & 15.6 & 10.7 & 35.8 & 8.78 & 47 \\
\hline PIA & 16.6 & 15.3 & 13.6 & 9.5 & 32.6 & 7.09 & 43 \\
\hline \multicolumn{8}{|c|}{ Bzura $(n=11)$} \\
\hline WIP & 4.4 & 3.4 & 3.8 & 1.1 & 10.1 & 91.21 & 2073 \\
\hline $\mathbf{V}$ & 0.3 & 0.3 & 0.3 & 0.2 & 0.6 & 0.17 & 57 \\
\hline CIA & 24 & 22.9 & 22.9 & 15 & 41.9 & 7.55 & 31 \\
\hline CIW & 24.7 & 23.6 & 23.5 & 15.3 & 43.4 & 8.65 & 35 \\
\hline PIA & 22.5 & 21.3 & 21.5 & 13.5 & 41.2 & 8.04 & 36 \\
\hline \multicolumn{8}{|c|}{ Narew $(n=30)$} \\
\hline WIP & 3.8 & 3.3 & 3.4 & 1.1 & 10.8 & 55.67 & 1465 \\
\hline $\mathbf{V}$ & 0.2 & 0.2 & 0.2 & 0.1 & 0.7 & 0.21 & 105 \\
\hline CIA & 18.9 & 17.3 & 17.8 & 6.8 & 43 & 7.27 & 38 \\
\hline CIW & 19.6 & 17.9 & 18.4 & 6.9 & 46 & 8.71 & 44 \\
\hline PIA & 16.8 & 15.1 & 16.1 & 5.5 & 41.9 & 6.82 & 41 \\
\hline \multicolumn{8}{|c|}{ Pilica $(n=13)$} \\
\hline WIP & 2.1 & 1.5 & 1.6 & 0.5 & 7.6 & 61.03 & 2906 \\
\hline $\mathbf{V}$ & 0.7 & 0.6 & 0.6 & 0.2 & 1.8 & 0.67 & 96 \\
\hline CIA & 38.4 & 35.5 & 36.2 & 18.1 & 67.7 & 13.62 & 35 \\
\hline
\end{tabular}




\begin{tabular}{c|c|c|c|c|c|c|c}
\hline CIW & 40.6 & 37.2 & 38 & 18.6 & 72.9 & 17.29 & 43 \\
\hline PIA & 37.9 & 34.4 & 34.9 & 16.5 & 70.6 & 15.79 & 42 \\
\hline \multicolumn{7}{c}{ Odra River basin(n=114) } \\
\hline WIP & 3.2 & 2.5 & 2.3 & 0.7 & 19.9 & 2.95 & 92 \\
\hline V & 0.8 & 0.7 & 0.8 & 0.1 & 2 & 0.46 & 58 \\
\hline CIA & 45 & 40.8 & 48.9 & 8 & 72 & 16.73 & 37 \\
\hline CIW & 48.4 & 43.7 & 52.9 & 8.9 & 76.7 & 18.57 & 38 \\
\hline PIA & 44.9 & 39.9 & 48.5 & 6.8 & 75 & 18.47 & 41 \\
\hline \multicolumn{7}{|c}{ Warta (n=26) } \\
\hline WIP & 2.5 & 1.9 & 1.8 & 0.8 & 11.8 & 2.70 & 108 \\
\hline V & 0.7 & 0.6 & 0.7 & 0.1 & 2 & 0.47 & 67 \\
\hline CIA & 37.3 & 34.2 & 37.8 & 8.9 & 67.4 & 13.82 & 37 \\
\hline CIW & 40.6 & 36.8 & 40.8 & 8.9 & 74.7 & 15.93 & 39 \\
\hline PIA & 36.1 & 32.6 & 35.6 & 8.4 & 71.6 & 15.06 & 42 \\
\hline
\end{tabular}

The CIA values in sediments of the Vistula River basin are in the range of 4-80; the mean is 27.6, geometric mean 24.3, and median 24.2. Standard deviation value is 14.07 and coefficient of variation is 51 (Table 3, Fig. 5).

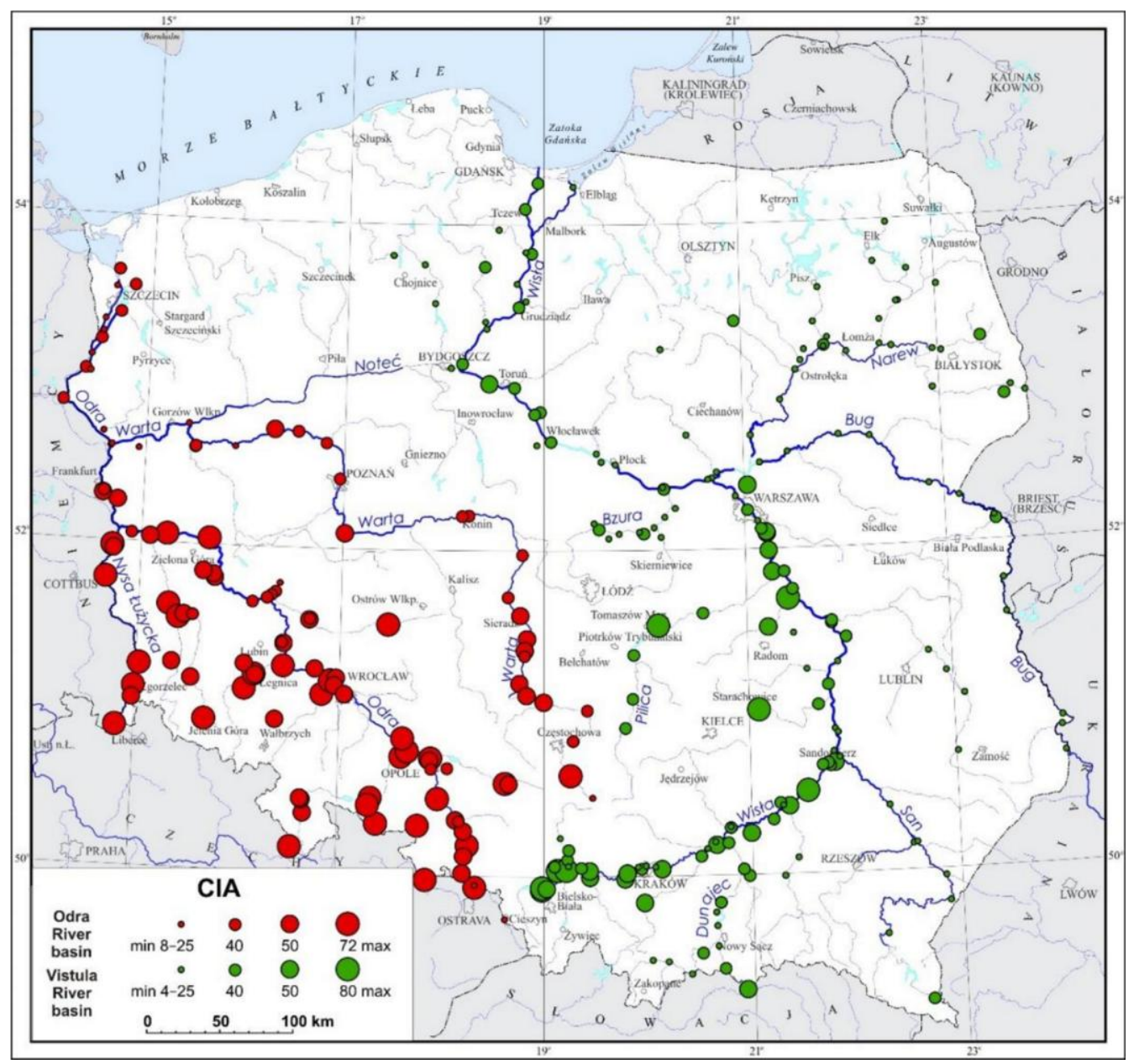

Figure 5. Chemical Index of Alteration values 
The highest values are found in sediments of the Pszczynka River in Jedlina and the Soła River (sands, gravels, alluvial muds and peats), while the lowest ones are observed in sediments of the Brda River in Tuchola (upon the bedrock composed of limestones, opokas, marls, phosphorites and cherts) and of the Wieprz River in Jaszczów (Cretaceous limestones, opokas and marls).

In sediments of the Vistula River basin, the CIW values varied from 4 (Brda River in Tuchola) to 82 (Pszczynka River in Jedlina), and the mean, geometric mean and median values were 28.9, 25.3 and 25, respectively. Standard deviation amounted 15.20 and coefficient of variation 53 (Table 3, Fig. 6).

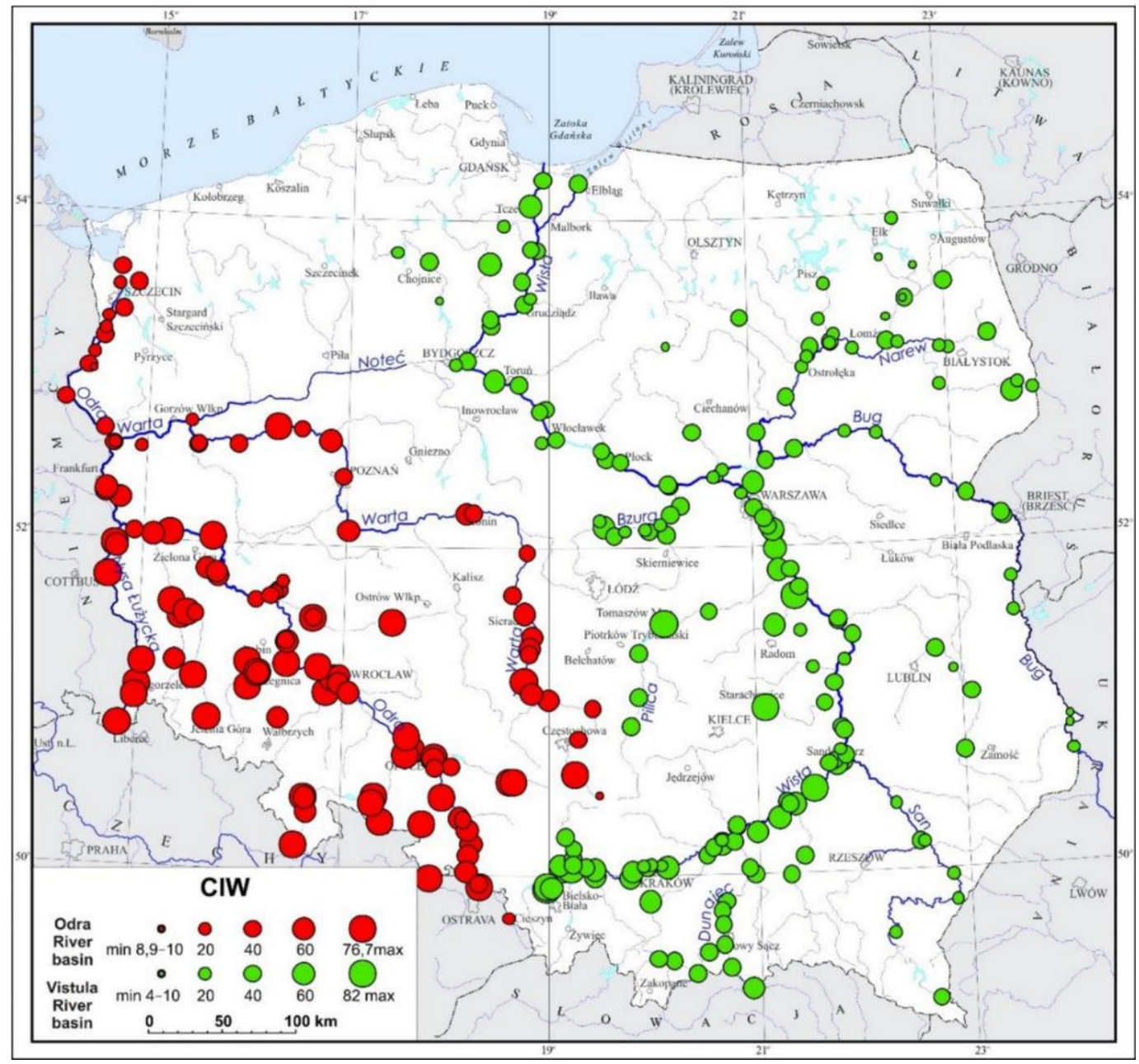

Figure 6. Chemical Index of Weathering values

The PIA values ranged from 3 (Brda River in Tuchola) to 81.7 (Pszczynka River in Jedlina); the mean was 26.2, geometric mean 22.5, and median 22.2, standard deviation 14.79 and coefficient of variation 56 (Table 3, Fig. 7).

In sediments of the Odra River basin, the Parker index values ranged from 0.7 to 19.9, and the mean, geometric mean and median values were 3.2, 2.5 and 2.3, respectively. Standard deviation and coefficient of variation values were 2.95 and 92 (Table 3, Fig. 1). The highest WIP value was found in sediments of the Olza River in Ropice (draining the Cretaceous carbonates), and the lowest one is reported from the 
Czerna Wielka River with the bedrock composed of sands, gravels and muds. The values of 17.1-10.1 were found in sediments of the Olszanka and Warta rivers in Kromołów and Santok.

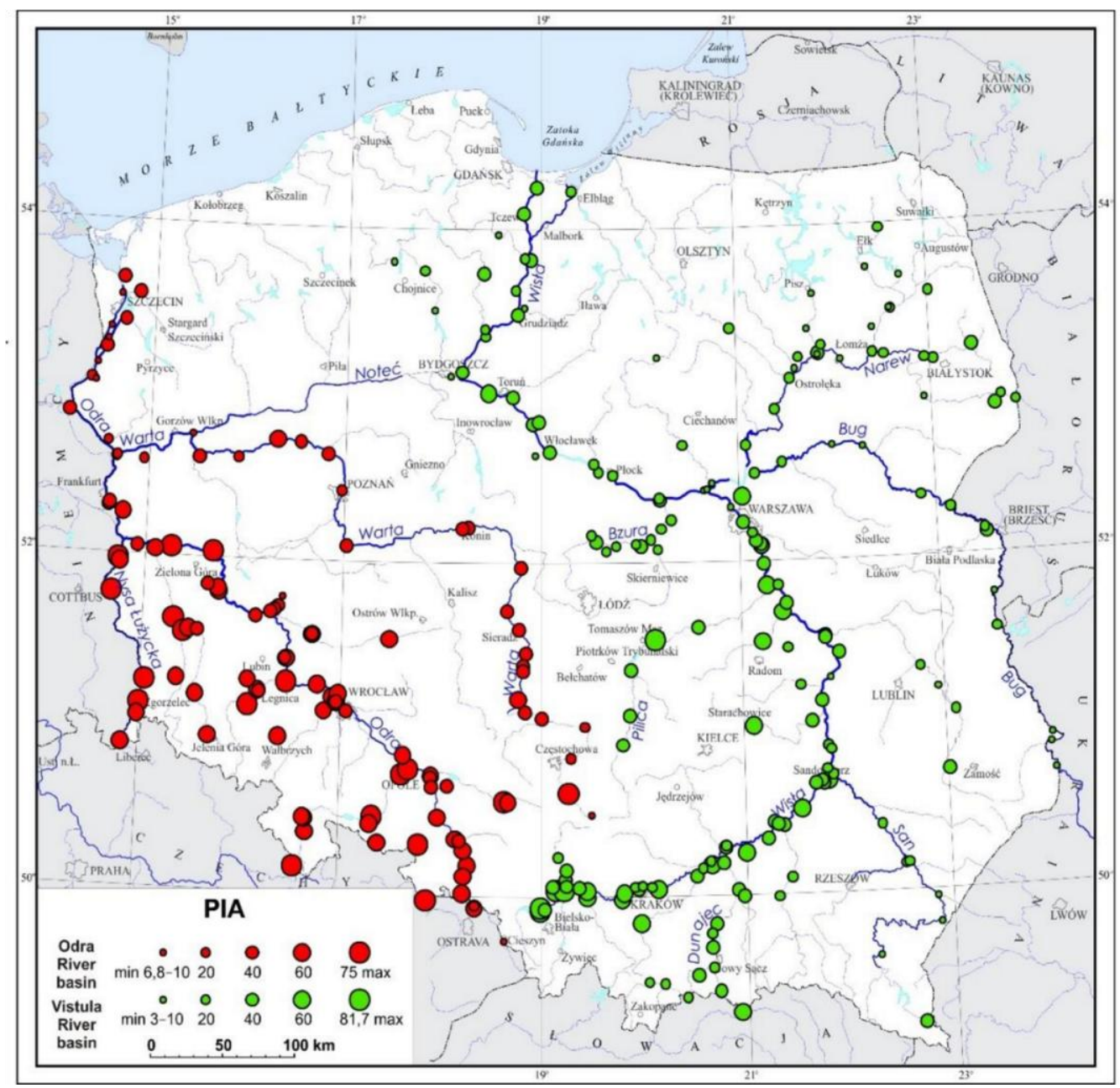

Figure 7. Plagioclase Index of Alteration values

The $\mathrm{V}$ index values in sediments of the Odra River basin are in the range from 0.1 (Warta River in Kromołów) to 2 (Zimny Potok stream in Ciemnice); the mean was 0.8, geometric mean 0.7, and median 0.8, standard deviation 0.46 and coefficient of variation 58 (Table 3, Fig. 4). The Vogt's index values are very high in the upper course of the Nysa Łużycka River, at its confluence with the Odra River, and at the confluence of the Kwisa and Bóbr rivers. The lowest values were recorded in the lower reach of the Odra River, at its mouth to the Baltic Sea, and near the confluence with the Warta River in the middle course of the Odra.

The CIA values varied between 8 and 72, and the mean, geometric mean and median values were 45, 40.8 and 48.9, respectively. Standard deviation and coefficient of variation values were 16.73 and 37, respectively (Table 3, Fig. 5). The highest levels were observed in sediments of the Nysa Łużycka River in Zasieki (sands, gravels, alluvial muds and peats), and the lowest values were recorded in sediments of the Rurzyca River near its confluence with the Odra (glacial tills in the bedrock). Very high 
values were also found in the Zimny Potok stream in Ciemnice (fluvial clays, muds and sands) and in the Nysa Łużycka River in Zgorzelec. Low values are reported from the Warta River in Kromołów - a district of Zawiercie (Jurassic limestones) - and from the Olza River (Cretaceous limestones and shales).

The CIW values ranged from 8.9 (Rurzyca River in Nawodna) to 76.7 (Nysa Łużycka River in Zasieki), and the mean, geometric mean and median values were 48.4, 43.7 and 52.9, respectively. Standard deviation amounted 18.57 and coefficient of variation was 38 (Table 3, Fig. 6).

The PIA values varied between 6.8 (Rurzyca River in Nawodna) and 75 (Nysa Łużycka in Zasieki), and the mean, geometric mean and median values were 44.9, 39.9 and 48.5, respectively. Standard deviation value was 18.47 and coefficient of variation value was 41 (Table 3, Fig. 7).

Graphical representation of the distribution of chemical weathering indices shows that they distinctly differ between the Odra basin and the Vistula basins, and that the WIP index reveals the lowest variability (Fig. 8).
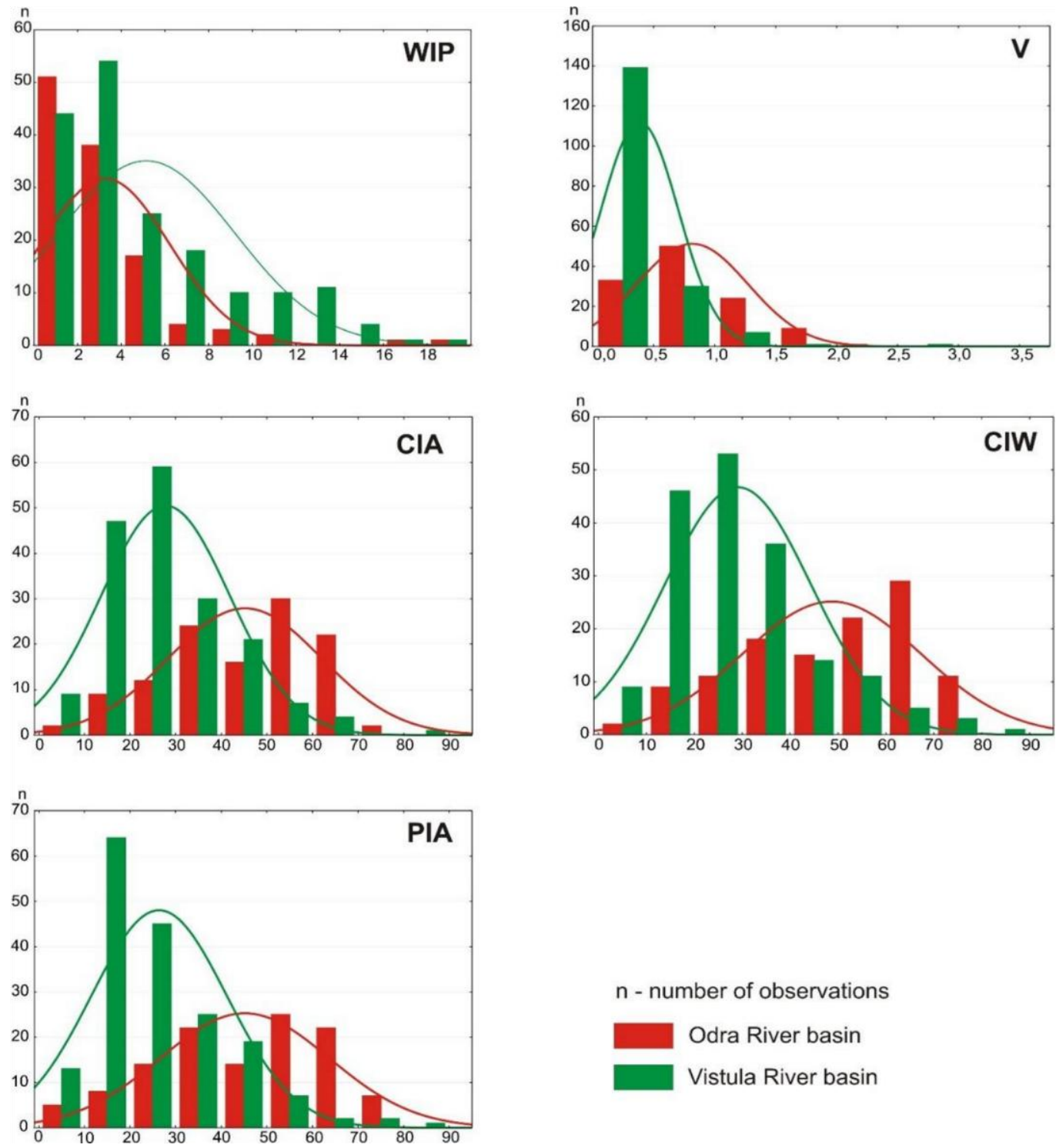

$\mathrm{n}$ - number of observations

Odra River basin

Vistula River basin

Figure 8. Histograms of chemical weathering indices 
The dominant WIP values in sediments of both basins are from 0 to 4 . In the case of the Odra basin sediments, the WIP values are usually in the range of $0-2$, and less frequently of 2-4. In the Vistula basin, the most common values vary from 2 to 4 , and less frequently from 0 to 2 . The CIA values in the Odra basin are generally in the range of 30-70, while in the Vistula basin they vary between 10 and 40 (Fig. 8). The distribution of the values of the plagioclase index of alteration is similar. The most common PIA values in the Odra basin sediments are in the range of 30-70, while in the Vistula basin they are between 10 and 50 (Fig. 8). In the Vistula basin, the dominant Vogt's index values are up to 0.5 , while in the Odra basin between 0.5 and 1.0. The CIW values also differ between both basins. In the Vistula basin, the dominant values are in the range of 10-40, while in the Odra basin they vary from 30 to 70 . In general, fluvial sediments in the Odra River basin are characterised by a greater number of samples with low values of the weathering indices than those in the Vistula basin, except for the WIP.

The most common values of the analysed indices (the percentile range is 25-75) in sediments of the drainage basins are well illustrated in the box plots (Fig. 9).
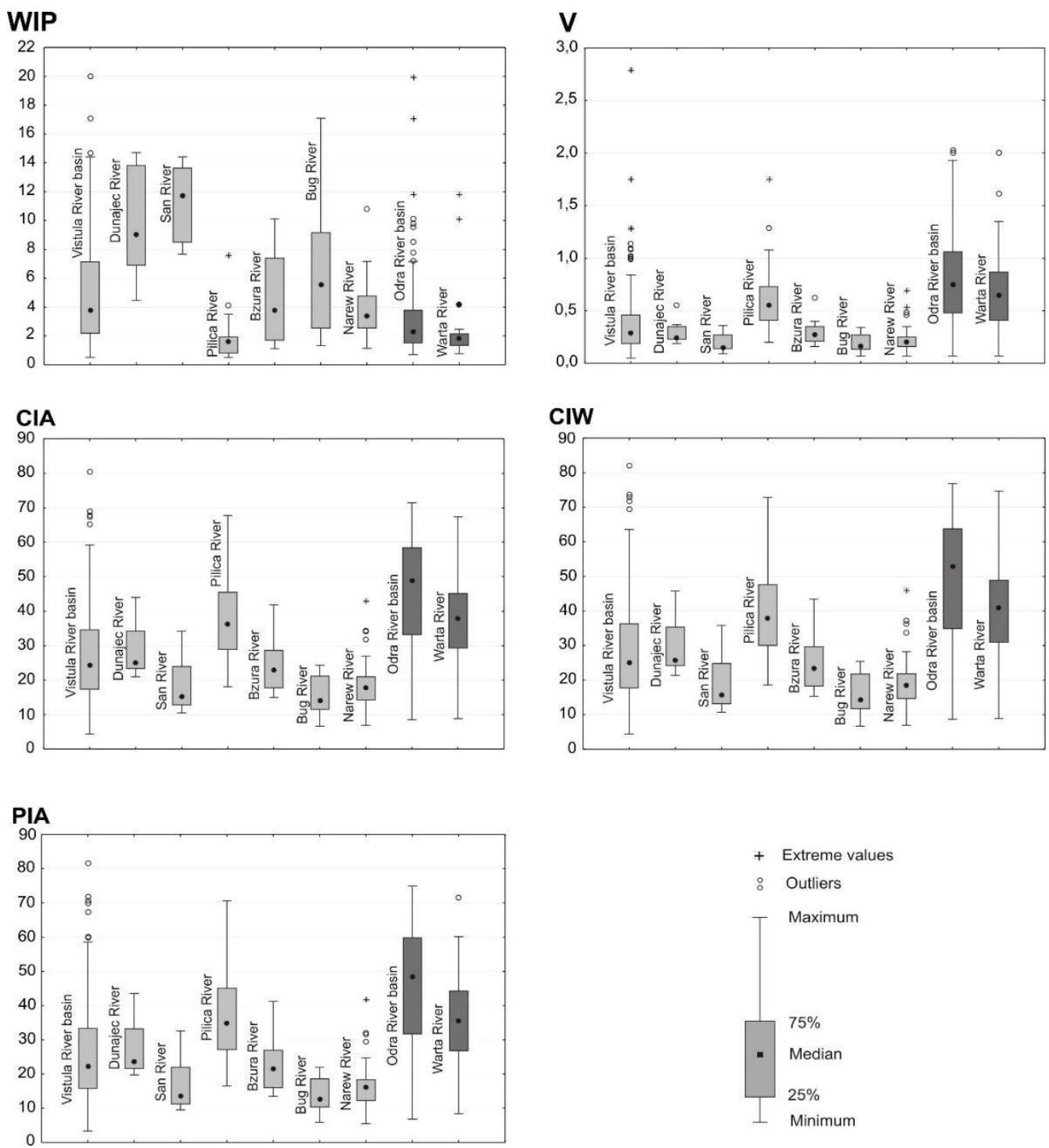

Figure 9. Boxplots of chemical weathering indices in sediments of selected rivers 
The range of the most common WIP values for sediments of the Odra basin (1.5-3.8) is much narrower than for those of the Vistula River system (2.2-7.1). For the Bug, Dunajec and Bzura rivers, the range is very wide, for the San River it is narrower, and the narrowest is for lowland rivers: the Narew, Pilica and Warta. The highest WIP values are observed in sediments of the drainage basins of the Dunajec and San rivers that drain the Carpathians and Subcarpathia. The lowest values are recorded in sediments of the Warta and Pilica basins (Fig. 9).

\section{Discussion}

The calculated indices are complementary and show similar trends. Sediments supplied into the Lower Odra River basin were subjected to stronger chemical weathering during transport (because they carry away more mobile elements) and mixing with the sediments of the Warta River.

High values of standard deviation and coefficient of variation indicate on a very extensive dispersion of data in relation to average values. Variability of data in the case of majority of elements for both Vistula and Odra River basins and their tributaries is below 100, what gives information about moderate differentiation of elements content. Much higher values than 100 in the case of $\mathrm{Ca}$ and $\mathrm{Mg}$ were present for Pilica, Odra and Warta River basins and they inform about huge results variability. It is worth highlighting that Warta and Pilica have their sources on Małopolska Upland area, which is built of carbonate rocks. Coefficient of variation values for V, CIA, CIW and PIA indices point to moderate diversification of results. WIP is an exception among them and its values vary from 604 (San) to 2906 (Pilica). These values show extremely huge variability of obtained results. CV values below 200 suggest that these elements distribution in sediments is moderately homogenous and mainly involved with their natural (lithogenic) origin. CV values above 200 indicate on uneven distribution of data set and suggest that the part of elements was artificially provided to the environment. It is clearly visible in Table 3.

The WIP values in sediments of the Odra and Vistula basins are much lower as compared with those from other regions of the world. The WIP value for samples of suspended fine particles in Chinese rivers varies from 24.7 to 58.3, and the average is 38.8. In samples from floodplain areas the values range from 26.4 to 59.4 , and the mean value is 44.4 (Shao et al., 2012). This index value in fluvial sands of Taiwan is in the range of 18-65 (Garzanti and Resentini, 2016), and it varies between 40.8 and 47.6 in stream sediments of the Alaknanda River basin (India) (Panwar and Chakrapani, 2016).

The range of the most frequent CIA values in the Odra basin (33.2-58.4) is wider than in the Vistula basin (17.4-34.6). The greatest variability of CIA values is observed in the case of sediments of the Pilica and Warta rivers. For the Bzura, Dunajec, San and Bug rivers, the variability is moderate, and for the Narew River it is the lowest.

The average CIA values calculated for the rivers of Poland are much lower than the average values for the rivers in the world, Asia and North America, although high levels have been sporadically recorded in some samples. The CIA value in sediments of various rivers across the world varies between 48.2 and 89.9 , and the average is 72 , with the highest levels in the African rivers (83.4 on average) as compared with the other continents. The lowest value observed in the North American rivers is 66.0. In the Asian rivers, the average value of this index is 71.7, which is close to the world's average. The highest CIA values are found in sediments of the Congo River (89.9), and the lowest 
ones are recorded in watercourses of the Kola Peninsula in the Arctic area (48.2) (Li and Yang, 2010). The CIA values in suspended matter of the Chinese rivers were between 58.8 and 91.3, with the average of 71.4, which is close to the world's average. In floodplain areas, the values varied from 44.5 to 84.3 , with the average of 61.3 . For comparison, sands of the Taiwan rivers show the CIA values in the range of 46-77. The values in the Chinese rivers are 72-88, and in the Alaknanda River basin (India) the average value is 56 (Garzanti and Resentini, 2016; Shao et al., 2012; Selvaraj and Chen, 2006; Panwar and Chakrapani, 2016). The highest levels of this index (88.9-94.5) were recorded in stream sediments of southwestern Nigeria (Madukwe et al., 2016).

The compilation of curves for V, CIA, CIW and PIA values for the individual river subbasins shows that they are comparable and the highest levels are observed in sediments of the Warta and Pilica river basins. In the remaining subbasins they are lower (Fig. 7). The similarity is undoubtedly due to the similar lithologies of the underlying rocks. The neighbouring drainage basins drain the area of the Mid-Polish Lowlands, and the rivers' headwaters are located within the Małopolska Upland, where limestones and marls are the important lithologic components.

The lowest V, CIA, CIW and PIA values are found in sediments of the drainage basins of the Narew, Bug and San rivers of eastern Poland, which drain areas of diverse geological structures. In the San drainage basin area, there are mainly flysch deposits. In the Bug River basin, carbonate-rich rocks (limestones, marls and loess) account for a considerable proportion, whereas in the Narew basin area there are only glacial deposits.

The $\mathrm{V}$ and CIW values in sediments of the Vistula and Odra river basins are definitely lower than in other regions of the world. The $\mathrm{V}$ index levels in weathering profiles of the Coweeta Basin, North Carolina, USA, are 1.9-16.2 (Price and Velbel, 2003). In sands of the Taiwan rivers, the CIW values are in the range of 47-95 (Garzanti and Resentini, 2016), and in stream sediments of Nigeria they vary between 89 and 98, locally reaching 95.3-98.2 (Gajere et al., 2015; Madukwe et al., 2016).

Similarly, the PIA values in the rivers of Poland are lower than the values observed in rivers of other climatic zones. In the fluvial sands of Taiwan, the PIA values vary from 46 to 94, and in sediments of the Kaoping River the average is 66 (Garzanti and Resentini, 2016; Selvaraj and Chen, 2006). The highest values of this index (94-98) were recorded in stream sediments of SW Nigeria (Madukwe et al., 2016).

In Poland, the length of sediment transport by rivers is likely to have little effect on the value of chemical weathering indices. Their decreasing values from the south towards the north of Poland in the analysed sediments of the whole study area indicate the dominant role of the chemical composition of bedrocks in the drainage basins.

This observation clearly confirms the different range and values of WIP, which are significantly smaller in the Odra River sediments than in the Vistula River sediments. The greatest variability of the WIP in the upper parts of the river basins (Fig. 1) is related to the drainage of igneous, metamorphic and sedimentary rocks of the Sudetes in the upper Odra River basin, and of the Carpathian flysch in the upper Vistula River basin. In the lower reaches of the rivers, the WIP, CIA, V and PIA values are less varied, indicating that their values are influenced mainly by the geological structure of those parts of the drainage basins where Quaternary deposits are exposed: glacial tills, clays, sands, gravels, peats and alluvial muds.

The greatest effect on the values of weathering indices in particular river subbasins can also be attributed to the lithologies. 
In the Bug River basin, the high WIP value and the low values of other indices are due to high calcium contents in sediments (derived from the drainage of loess, limestones and marls). In contrast, the Warta and Pilica river basins, which drain Quaternary deposits over almost the entire drainage basins, the WIP values are the lowest, as opposed to the values of the other indices (Fig. 7).

CIA values are used to assess the effect of climate on the rate and mode of weathering more often than the other indices are. At lower geographical latitudes, the average annual temperatures are higher and the intensity of chemical weathering decreases. In the present research, the CIA values show a dependence on the average annual temperature and precipitation. A moderate level of chemical weathering dominates in central Poland (Wielkopolska Lake District, Wielkopolska Lowland and Mazovian Lowland), in the area of the lowest annual precipitation. Fluvial sediments in northern Poland (Lower Odra and Lower Vistula drainage basins), with elevated annual precipitations $(600-700 \mathrm{~mm})$, are characterised by the highest degree of weathering. High weathering levels are also typical of sediments in the Sudetes and the Carpathians, where the annual precipitation is $800-1200 \mathrm{~mm}$. The high intensity of chemical weathering in the Carpathians is best illustrated by the CIA values, while in the Sudetes by the WIP values.

\section{Conclusions}

1. The values of weathering indices in river sediments of Poland vary in a wide range, but they are lower than the values found in other warmer and humid climates of the world.

2. The values of weathering indices in river sediments are affected mainly by the chemical composition of bedrocks of the drainage basins. In those parts of the drainage basins, which are underlain by pre-Quaternary rocks, the sediments show greater resistance to chemical weathering and lower susceptibility to leaching of elements. The highest losses of elements due to leaching are characteristic of the lower parts of the Odra and Vistula drainage basins composed of Quaternary deposits.

3. The degree of chemical weathering of sediments of the analysed rivers of Poland varies according to climatic conditions that differ between the north and the south of the country. The highest degree of weathering is observed in the lower drainage basins of the Odra and Vistula rivers and in mountainous areas (the Sudetes and the Carpathians). In central Poland, the moderate degree of chemical weathering is dominant.

4. Comparison of chemical weathering indices variability in river sediments in southern Poland will be very worthwhile, especially in the Carpathians e.g. Dunajec and Wisłoka rivers and in the Sudetes (Nysa Łużycka and Bóbr).

\section{REFERENCES}

[1] Bahlburg, H., Dobrzinski, N. (2011): A Review of the Chemical Index of Alteration (CIA) and Its Application to the Study of Neoproterozoic Glacial Deposits and Climate Transitions. - In: Arnaud, E., Halverson, G. P., ShieldsZhou, G. A. (eds.) The Geological Record of Neoproterozoic Glaciations. Memoir 36, pp. 81-92. Geological Society, London. 
[2] Bäumler, R., Zech, W. (2000): Quaternary paleosols, tephra deposits and landscape history in South Kamchatka, Russia. - Catena 41: 199-215.

[3] Bilinski, H. (2008): Weathering of sandstones studied from the composition of stream sediments of the Kupa River (Croatia). - Mineralogical Magazine 72(1): 23-26.

[4] Bojakowska, I., Sokołowska, G. (1998): Geochemiczne klasy czystości osadów wodnych. - Przegląd Geologiczny 46(1): 49-54.

[5] Bojakowska, I., Gliwicz, T., Małecka, K. (2006): Wyniki geochemicznych badań osadów wodnych Polski w latach 2003-2005. - Biblioteka Monitoringu Środowiska, Warszawa.

[6] Bland, W., Rolls, D. (1998): Weathering. An Introduction to the Scientific Principles. Arnold Publishers, London.

[7] Cempiel, E., Czajkowska, A., Nowińska, K., Pozzi, M. (2014): Przejawy antropopresji w zlewni rzeki Bytomki. - Wyd. Pol. Śl., Gliwice.

[8] Chetelat, B., Liu, C., Wang, Q., Zhang, G. (2013): Assessing the influence of lithology on weathering indices of Changjiang river sediments. - Chemical Geology 359: 108-115.

[9] Ciszewski, D. (1997): Source of pollution as a factor controlling distribution of heavy metals in bottom sediments of Chechło River (south Poland). - Environmental Geology 29: 50-57.

[10] Ciszewski, D. (2002): Zapis działalności przemysłowej w osadach fluwialnych. - In: Szwarczewski, P., Smolska, E. (ed.) Zapis działalności człowieka w środowisku przyrodniczym. Vol I, pp. 23-28. Łomża, Warszawa.

[11] Ciszewski, D. (2005): Osady pozakorytowe Odry jako archiwum historii zanieczyszczenia rzeki metalami ciężkimi. - In: Kotarba, A., Krzemień, K., Święchowicz, J. (ed.) Współczesna ewolucja rzeźby Polski. VII Zjazd Geomorfologów Polskich, pp. 60-67. IGiGP UJ, Kraków.

[12] Cwojdziński, S., Kozdrój, W. (2007): Sudety Przewodnik Geoturystyczny wzdłuż trasy drogowej Nysa-Złoty Stok-Kłodzko-Wałbrzych -Jelenia Góra. - Państwowy Instytut Geologiczny, Warszawa.

[13] Delvaux, B., Herbillon, A. J., Vielvoye, L. (1989): Characterization of a weathering sequence of soils derived from volcanic ash in Cameroon. Taxonomic, mineralogical and agronomic implications. - Geoderma 45: 375-388.

[14] Eswaran, H., Stoops, G., De Paepe, R. (1973): A contribution to the study of soil formation on lsla Santa Cmz, Galiipagos. - Pedologie 23: 100-122.

[15] Fedo, C. M., Nesbitt, H. W., Young, G. M. (1995): Unraveling the effects of potassium metasomatism in sedimentary rocks and paleosols, with implications for paleoweathering conditions and provenance. - Geology 23: 921-924.

[16] Fedo, C. M., Eriksson, K. A., Krogstad, E. J. (1996): Geochemistry of shales from the Archean $(\sim 3.0 \mathrm{Ga})$ Buhwa Greenstone Belt, Zimbabwe: implications for provenance and source-area weathering. - Geochimica et Cosmochimica Acta 60: 1751-1763.

[17] Gajere, J. N., Abaa, S. I., Kana, J. E. (2015): Paleoenvironmental studies for stream sediments around Awe-Obi area North Central Nigeria. - Geology \& Geosciences 4(2): 197. http://dx.doi.org/10.4172/2329-6755.1000197.

[18] Garzanti, E., Resentini, A. (2016): Provenance control on chemical indices of weathering (Taiwan river sands). - Sedimentary Geology 336: 81-95.

[19] Gupta, A. S., Rao, K. S. (2001): Weathering indices and their applicability for crystalline rocks. - Bulletin of Engineering Geology and the Environment 60: 201-221.

[20] Harnois, L. (1988): The CIW index: a new Chemical Index of Weathering. - Sedimentary Geology 55: 319-322.

[21] Haskins, D. (2006): Chemical and mineralogical weathering indices as applied to a granite saprolite in South Africa. - IAEG2006, Paper number 465, Geological Society of London.

[22] Kondracki, J. (2009): Geografia regionalna Polski. - PWN, Warszawa.

[23] Li, C., Yang, S. Y. (2010): Is chemical index of alteration a reliable proxy for chemical weathering in global drainage basins? - American Journal of Science 310: 111-127. 
[24] Madukwe, H. Y., Ayodele, S. O., Akinyemi, S. A., Adebayo, O. F. (2016): Classification, maturity, provenance, tectonic setting, and source-area weathering of Ipole and Erin Ijesa stream sediments, south west Nigeria. - International Journal of Advanced Scientific and Technical Research 6(1): 232-255.

[25] Marks, L., Ber, A., Gogołek, W., Piotrowska, K. (2006): Mapa geologiczna Polski 1:500 000. - Państwowy Instytut Geologiczny, Warszawa.

[26] Neall, V. E. (1977): Genesis and weathering of andosols in Taranaki, New Zealand. Soil Science 123: 400-408.

[27] Nesbitt, H. W., Young, G. M. (1982): Early Proterozoic climates and plate motions inferred from major element chemistry of lutites. - Nature 299: 715-717.

[28] Panwar, S., Chakrapani, G. J. (2016): Seasonal variability of grain size, weathering intensity, and provenance of channel sediments in the Alaknanda River Basin, an upstream of river Ganga, India. - Environmental Earth Sciences 75: 998. DOI: 10.1007/s12665- 016-5815-y.

[29] Parker, A. (1970): An index of weathering for silicate rocks. - Geological Magazine 107: 501-504.

[30] Price, J. R., Velbel, M. A. (2003): Chemical weathering indices applied to weathering profiles developed on heterogenous felsic metamorphic parent rocks. - Chemical Geology 202: 397-416.

[31] Richling, A., Ostaszewska, K. (2005): Geografia fizyczna Polski. - Wyd. PWN, Warszawa.

[32] Roaldset, E. (1972): Mineralogy and geochemistry of Quaternary clays in the Nuinedal Area, southern Norway. - Norsk Geolisk Tidsskrift 52: 335369.

[33] Selvaraj, K., Chen, T. A. (2006): Moderate chemical weathering of subtropical Taiwan: constraints from solid-phase geochemistry of sediments and sedimentary rocks. - Journal of Geology 114: 101-116.

[34] Shao, J., Yang, S., Li, C. (2012): Chemical indices (CIA and WIP) as proxies for integrated chemical weathering in China: Inferences from analysis of fluvial sediments. Sedimentary Geology 265-266: 110-120.

[35] Sharma, A., Rajamani, V. (2000): Major element, REE, and Rother trace element behavior in amphibolite weathering under semiarid conditions in southern India. Journal of Geology 108: 487-496.

[36] Vogt, T. (1927): Sulitjelmafeltets geologi og petrografi. - Norges Geologiske Undersokelse 121: 1-560 (in Norwegian, with English abstract).

[37] Woś, A. (2010): Klimat Polski w drugiej połowie XX wieku. - Wyd. UAM, Poznań. 